
internationales

vol. 22 - $n^{\circ} 3 \mid 2006$

Turquie 2006 : aux portes de l'Union européenne?

\title{
A Panorama of the International Migration Regime in Turkey
}

Ahmet İçduygu

\section{(2) OpenEdition}

1 Journals

Electronic version

URL: https://journals.openedition.org/remi/3221

DOI: 10.4000/remi.3221

ISSN: $1777-5418$

Publisher

Université de Poitiers

Printed version

Date of publication: 31 December 2006

Number of pages: 11-21

ISBN: 978-2-911627-43-9

ISSN: 0765-0752

\section{Electronic reference}

Ahmet Içduygu, "A Panorama of the International Migration Regime in Turkey", Revue européenne des migrations internationales [Online], vol. 22 - $n^{\circ} 3$ | 2006, Online since 31 December 2009, connection on 15 April 2022. URL: http://journals.openedition.org/remi/3221 ; DOI: https://doi.org/10.4000/remi. 3221

This text was automatically generated on 15 April 2022

(c) Université de Poitiers 


\title{
A Panorama of the International Migration Regime in Turkey
}

\author{
Ahmet İçduygu
}

1 In 2005 the major determinant of migration-related practices and policies in Turkey was to the opening of accession negotiations with the European Union on $3^{\text {rd }}$ of October, 2005 ${ }^{1}$. After extenuating political debate and diplomatic efforts, on 17 December 2004, the European Union agreed to begin accession negotiations with Turkey and then Turkey did indeed start negotiations. These events were hailed as a major political success for the Turkish government, but posed a series of questions. Will accession to the EU generate massive, and undesired, flows of Turkish citizens to EU countries? How will flows of transit migration through Turkey be managed? Whether inflows of Turkey's young population to other parts of the EU will offset the ageing population of the latter? And whether the occupational profile of Turkey's potential migrant population is compatible with that of its EU neighbours, or whether it will generate disturbances on the labour market?

2 These issues, together with the fact that Turkey is no longer solely a country of emigration, but has also become a country immigration and transit - will continue to be key issues on the EU-Turkey migration agenda. In its recent recommendations on Turkey's progress towards accession in the early October 2004 the European Commission noted that:

"With over three million, Turks constitute by far the largest group of third-country nationals legally residing in today's EU [...], the management of the EU's long new external borders would constitute an important policy challenge... managing migration and asylum as well as fighting... trafficking of human beings... would be facilitated through closer cooperation both before and after accession"

3 As widely observed, Turkey's EU membership question has been controversial since the beginning. The possible immigration pressure the EU would experience as a result of Turkish membership, and eventual free circulation of labour, is one issue that is constantly brought up within this context. In particular, as far as the EU 25 public opinion on Turkey's membership is concerned, EU citizens worry most about immigration-related issues. ${ }^{3}$ 
4 In contrast, with regard to the dominant image of Turkey in the EU 25 public opinion which often views the country as one with established economic hardship and emigration pressure, Turkey in 2005 has continued to witness a remarkable and multifaceted transformation almost in all sectors of the economy. The period 2003-2005 was characterised by a range of remarkable developments in the Turkish economy. After the worst economic crisis on record in the late 1990s, in the early 2000s the economy began a slow but steady recovery, with the help of an IMF-supported programme of structural change and the liberalisation of its financial markets, after which Turkey became one of the most dynamic economies of Europe. GNP grew by $7.8 \%$ in 2002 , compared to 2001 , by $5.9 \%$ from 2002 to 2003 , and finally by $9.9 \%$ to 2004 . After the historical level recorded in 2004, despite a relative decline in the rate, GNP rose by $7.6 \%$ in 2005. Per capita income also increased to US\$2,584 in 2002, to US\$3,383 in 2003 , and to US\$ 4240 in 2004 indicating an increase of almost $26 \%$ in the space of a single year.

5 It should be underlined that Turkey's per capita income has rose above US $\$ 5.000$ in 2005 for the first time ever. There was a sharp decline in the remarkably high level of inflation: the consumer price index dropped by more than $57 \%$ in 2002 , by nearly $37 \%$ in 2003 , and by nearly $50 \%$ in 2004 . The process of disinflation has been impressive with the inflation rate declining from $54 \%$ in 2001 to $18 \%$ in 2003 and less than $8 \%$ in 2005. In 2002 the devaluation of the Turkish Lira slowed down considerably and in 2003 it regained its value against US\$: 1 US\$ to 1.4 million Turkish Lira, and almost same level as for 2001. In 2004 and 2005, it kept the same level: 1 US\$ to 1.3 New Turkish Lira.

6 In contrast to these positive developments, Turkey's heavy debt burden continued to weaken the country's economic performance in the period 2003-2005. In 2003, total domestic debt amounted to over $58 \%$ of GNP, and the total foreign debt remained around $62 \%$ of GNP. In 2004 total domestic debt was $52 \%$ of GNP and the total foreign debt amounted to $54 \%$ of GNP. There were some improvements in the ratios of total foreign and debt stock to the GNP in 2005: they declined by $8 \%$ and $2 \%$ respectively. Relatively high interest rates, high levels of public deficit, and an economic climate generally lacking in confidence prevented any significant level of investment. It is not surprising that the Turkish labour market continued to experience serious problems, with over 2.5 million unemployed and nearly one million underemployed out of an economically active population of over 24 million in 2005.

\section{Trends In Emigration}

7 In recent decades there have been five main types of emigration of Turkish citizens: ${ }^{4}$ family-related emigration; asylum-seeking; irregular (undocumented or clandestine) labour emigration; contract-related (low-skilled) labour emigration; and international professional emigration.

8 There is no direct and reliable Turkish data source on these flows of emigration. However, data on emigration from Turkey are available indirectly from reports on immigration in receiving countries. Consequently, this report has had to draw largely on variable quality sources, ${ }^{5}$ including statistics in the destination countries and Turkey, which give a very general, descriptive and documentary picture of the overall emigration history. 
9 Family-related migration is mainly due to the presence of sizeable Turkish migrant communities in the migrant-receiving countries in which networks keep the migratory flows continuously active. Long and short-term family related visits, family reunification and marriage-related migration where brides and grooms from Turkey join spouses living abroad, account for a significant part of Turkish emigration. These movements are primarily directed to Western European countries, and to a certain extent, to Australia and North America. From numbers of arrivals of Turkish citizens in several migrant-receiving countries, we can estimate that by the mid-1990s nearly 100.000 emigrants would leave Turkey annually, a vast majority of them directed to Europe and nearly half of them due to family ties with those already living abroad, ranging from long-term visits for at least three months to long-term residence permits for a year or family reunification schemes.

Overall, in the second half of the 1990s, there was a considerable decline in the familyrelated movement. It is estimated that the total number of Turkish emigrants to Europe may fall to the level of 50.000 per year in the early 2000s and nearly one third of them are those who moved in the family-related flows. It is assumed that quite similar trends continued in 2005.

11 Asylum-seeking contributed considerably to the overall level of emigration in the late 1990s and early 2000s. Data from the United Nations High Commissioner for Refugees (UNHCR) shows that the annual flows of asylum-seekers from Turkey to Europe were almost 28.000 in 2000, 30.000 in 2001, 28.000 in 2002 and 23.000 in $2003^{6}$. It continued to decrease in 2004 retreating to 16.000 and finally to $1120^{7}$ in 2005 . The numbers of asylum-seekers from Turkey increased continuously from the late 1990 s to the early 2000s, then declining since 2002. The size of established immigrant communities in the receiving countries appears to be heavily dependent on levels of asylum flows to those countries: for instance, in 2001 a large proportion of asylum-seekers from Turkey to Europe entered countries with a sizeable Turkish community, such as Germany ( $36 \%$ of asylum-seekers) and France (18\%). In 2002 these figures were $34 \%$ and $23 \%$ respectively. In $2003,28 \%$ of asylum-seekers from Turkey arrived in Germany, and $27 \%$ of them reached France. In 2004, the figure for Germany increases to $44 \%$ while the figure for France decreases to $11 \%$. In $2005,31 \%$ of asylum seekers from the country arrived in France and $25 \%$ went to Germany.

12 Turkey generates asylum-seekers to Europe directly, and indirectly as a transit country for asylum-seekers from neighbouring countries. For instance in 2001, 112.000 asylumseekers from Afghanistan, Iran and Iraq arrived in Europe, and accounted for over a quarter of total asylum-seekers to the continent. In 2003, their number had declined to below 50.000 and it continued to decline to 30.000 in 2004 and to 28.000 in 2005, accounting for over $10 \%$ of asylum seekers to Europe. One could assume that a significant portion of these asylum seekers had used Turkey as a transit zone before reaching Europe.

13 Given the nature of irregular labour migration it is extremely difficult to give accurate estimates. It includes "illegal entries", "overstayers", and "rejected asylum-seekers", and this diversity makes estimating their number even more difficult. In addition, family-related migration and asylum-seeking, may contribute to the categories of "overstayers" and "rejected asylum-seekers". In a study conducted in the late 1990s in Turkey, of all the interviewed international migrants, nearly one quarter stated that they have tried to enter a country without the required papers $(11 \%)$ or attempted to 
overstay their visa or permit (11\%), (İçduygu \& Ünalan, 2002). Anecdotal evidence of irregular migration in Turkey and Europe indicate that although there were still ongoing flows of irregular migration, the trend was on the decline. For instance, there were 2.350 Turkish citizens apprehended in Central and Eastern Europe as irregular migrants in 2004 and this figure had drop to 2.124 in 2005 (Futo \& Jandl, 2006). In recent years contract-dependent labour migration has constituted a large part of Turkish emigration. In 2000, 13.645 workers obtained employment abroad through the Turkish Employment Office (TEO). This figure leapt to over 20.000 in 2001, to 27.000 in 2002 , to 34.000 in 2003 , to 40.000 in 2004 , and to over 60.000 in 2005. This migration was primarily a contract-dependent labour migration, where workers are hired for a period of 3-24 months by Turkish or foreign contracting firms operating mainly in the Commonwealth of Independent States (CIS) and in Arab countries. In 2000, over half (52\%) these workers went to the CIS, $18 \%$ to the Arab countries, $17 \%$ to EU countries, and $10 \%$ to Israel. In that year the Russian Federation, Germany, Turkmenistan, Saudi Arabia, and Uzbekistan were the top five receiving countries for Turkish workers. In 2003, the top ranking was Russian Federation (31\%), Saudi Arabia (17\%), Germany (10\%), Libya (7\%), and Turkmenistan (4\%). It appeared that in 2004 while one third of these migrants went to Russian Federation, more than $12 \%$ moved to Iraq, and $10 \%$ to Kazakhstan. In 2005, the top three destination countries were still the same countries: Russian Federation (32\%), Iraq (12\%), and Kazakhstan (9\%).

This type of migration to EU countries was almost entirely directed to Germany, based on a bilateral agreement of 1991 which allowed German firms co-operating with Turkish partners to hire Turkish workers. The total number of Turkish workers who found employment in Germany in this framework in 2000 was 2.100, accounting for over $90 \%$ of the total workers sent to Europe by the Turkish Employment Office (TEO). This figure was $82 \%$ in $2001,85 \%$ in $2002,78 \%$ in 2003 , and $71 \%$ in 2004 . In 2005 , there were over 1.000 contract-based Turkish workers sent to Germany, accounting for $63 \%$ of the workers sent by TEO to the EU countries in the context of the same migration scheme.

Although there are no adequate data on this type of migration, one can assume that there has been a considerable flow of university graduates and skilled labour, particularly in the areas of computer sciences, finance, and management, amounting to an annual figure of around 2000-3000 individuals. The main destination countries are the traditional migrant-receiving countries such as Australia, Canada, the USA, and some European countries.

\section{Trends In Immigration}

Immigration has been an essential and constitutive element since the early days of Turkey's existence as a nation-state, with international migration to Turkey being almost exclusively constituted of ethnic-Turkish population from bordering countries. Therefore, until recently it was confusing to talk of a "real" foreign (ethnically nonTurkish) population originating from immigration in Turkey. It is the immigration of recent decades which is historically atypical for Turkey, consisting largely of transit migrants and clandestine labourers, asylum-seekers and refugees, who began to arrive in small numbers and subsequently in an ever-rising tide which has reached sizeable figures in recent decades. In the last decade, the influx of foreign nationals, mostly 
from the countries bordering on Turkey and from other nearby countries and regions, has continued at a significant level. There are two other components of immigration to Turkey: the more recent legal migrations of professionals and skilled migrants, and the ongoing migration of foreign-national ethnic-Turks living in other countries.

Although arrival and departure statistics in Turkey do not distinguish between migrants and tourists, they do provide a basis from which to reflect some rough implications for immigration. Overall, in recent years, around one third of nonnationals arriving in Turkey come from the neighboring regions, the Middle East, the $\mathrm{EU}$ and the CIS countries. The high levels of arrivals (for instance, 16\% in 2005) from the CIS countries are particularly striking. For a detailed account of arrival and departure statistics available in Turkey. The inflow of foreign nationals has become increasingly important in the last decade. Besides the migration of ethnic-Turks, often taking the form of asylum, there are four main types of inflows: transit migration flows; illegal labour migration; asylum-seekers and refugees; and registered migration of nonnationals. The first three types of inflow often overlap.

It is estimated that in 2001 over 258.000 foreign nationals were recorded as migrants in Turkey according to the four types of migratory flows mentioned above. Less than twothirds (around 161.000) were legal immigrants, and 92.000 were irregular (undocumented/clandestine) and/or transit migrants. Asylum-seekers account for a very small proportion of (2\%) of the flows of foreign nationals. In 2002, the total number of migrants registered in Turkey was just over 240.000, and in 2003 it declined to 212.000 . Over 56.000 of these migrants (approximately 25\%) were undocumented. In 2004, there were 61.200 undocumented migrants and around 3.900 asylum-seekers, in addition to over 155.000 foreigners who received their residence permits in the country. In 2005, there were over 178.000 foreign persons in Turkey who recorded as migrants of various kinds: 44,000 (24\%) irregular migrants, 4.000 (3\%) asylum-seekers and 137.000 (73\%) regular migrants with residence permit.

Since the early 1980s, Turkey has become a major country of asylum. Regime-change in Iran and then the Iran-Iraq War, the Gulf War of 1990-91, the subsequent political turmoil in Iraq and the US invasion contributed to the asylum flows to Turkey. Although based on its "geographical reservation" in the 1951 Geneva Convention, Turkey does not accept non-European refugees on de jure basis, it is a de facto situation that almost all asylum applications in the country are made by non-Europeans. From the late 1990 s to the early 2000s, Turkey was received approximately $5.000-6.000$ asylum applications a year. As a pragmatic solution, the Turkish authorities, together with the UNHCR Office in Ankara, agreed handle all applications and then the UNHCR tries to find a re-settlement country outside Turkey for those accepted non-European cases. In the last two years, asylum applications in Turkey have come from over thirty different countries, mainly in the Middle East, Africa and Asia. Iran and Iraq are the two main source countries of asylum-seekers. For instance, in 19993.800 Iranians and 2.500 Iraqis sought asylum in Turkey. The corresponding figures in 2000 were 3.700 and 1.600 respectively.

20 There are also nearly 100 asylum-seekers annually from countries as diverse as Afghanistan, Algeria, China, Kenya, Sri Lanka, Somalia, Nigeria, and Uzbekistan. ${ }^{7}$ Trends in asylum applications in 2001, 2002 and 2003 indicate major changes in terms of numbers from the main source countries: less than 400 Iraqi asylum-seekers in 2003 compared with nearly 1.000 in 2001 ; while the number of Iranian asylum-seekers 
slightly increased from 2.500 in 2002 to over 3.100 in 2003. There was a notable change in the composition of asylum-seekers to Turkey in 2003, as the numbers coming from some African countries increased slightly. For instance there were 183 Somali and 64 Sudanese citizens who sought asylum in 2003. Compared to the figure of 3966 in 2003, having a figure of 3,908 in 2004 and 3914 in 2005, there was a slight decline in the number of people seeking asylum in Turkey. The most significant change occurred in the case of Iranians when the number of asylum-seeker dropped from 3.108 to 1.716 from 2003 to 2004. Interestingly, there was a considerable increase in the number of Iraqi asylum-seekers, with a change from 342 in 2003 to 1047 in 2005.

There are three main types of irregular migration flows into Turkey: that of clandestine workers; that of transit migrants; and that of (rejected) asylum-seekers. The first are foreign nationals from Eastern European countries such as Moldova, Ukraine, Romania and CIS countries in search of employment. Various economic sectors in westerns Turkey particularly textile, sex and entertainment, construction, etc, rely on this form of cheap labour, while upper and middle-class Turkish families employ female domestic helpers as babysitters or carers for the sick and elderly. Many of them enter Turkey legally in accordance with Turkish visa requirements but overstay their visas and subsequently become illegal while in the country.

The second are irregular migration involves transit migrants who come to Turkey mainly from the Middle East (Iran, Iraq and recently Afghanistan), and from Asia and Africa (Pakistan, Bangladesh, Sri Lanka, Nigeria, Somalia, Congo). Turkey has been a key actor in international transit migratory movements for the last two decades. Thousands of migrants, with the intention of temporary stay, enter Turkey and find their way to the developed countries in the West and North. Some of these transit migrants arrive legally with tourist visas, but often drift into illegality as they overstay their right of entry, or try to enter a third country without proper travel documents. In this 'waiting' period, most go underground and work illegally.

The third form consists of rejected asylum-seekers who are reluctant to return home. As they do not have working permits under Turkish law, they look for illegal forms of employment. It is significant to note that Turkey - a signatory of the 1951 Geneva Convention with its 'geographical reservation' - only grants asylum to persons from Eastern Europe and the CIS. Taking into consideration the fact that thousands of asylum-seekers originate from the Middle East, unless granted refugee status and earn the right to settle in a third country, many of them will go underground and work illegally.

Although some senior officials ${ }^{8}$ claim the presence of around 'one million illegal foreign workers' in Turkey, there is no direct and reliable data on undocumented immigration. However some indicative numbers are available. The Bureau for Foreigners, Borders, and Asylum at the Directorate of General Security of the Ministry of Interior reports that there were nearly 95.000 reported cases of irregular migration in 2000. Data on the numbers of irregular migrants who have been apprehended indicate a considerable decline in these numbers from 2000 to 2005: around 44.000 irregular migrants were apprehended in 2005 compared with over 94.000 in 2000. In 2005, two-thirds of undocumented migrants were caught when entering or departing illegally, and onethird were overstayers.

In 2005, the first ten source countries were: Pakistan (25\%), Iraq (9\%), Moldova (8\%), Georgia (5\%), Afghanistan (5\%), Bangladesh (4\%), Ukraine (4\%), Iran (3\%), Romania 
(3\%), and Russian Federation (3\%). Although the number of these apprehended migrants has been declining steadily from the late 1990s to the early 2000s, the composition of migrants has changed significantly: there was a decline in the numbers from Russian Federation, Moldova, Iraq and Iran, but an increase in the numbers coming from countries in Asia, such as Pakistan, Bangladesh and India. Overall, the annually declining numbers of irregular migrants in recent years may be an indication of less irregular migrants entering Turkey, and improved methods of control and apprehension of the Turkish authorities.

The number of residence permits issued by the Directorate of General Security is an indirect measure of regular immigration to Turkey. Permits are issued for durations of residence of more than one month. Turkey draws a significant number of immigrants primarily from the Turkish-speaking populations of the neighbouring countries: in 2001 , the total number of residence permits was around 161.000 , over 58.000 coming from Bulgaria, 10.000 from Azerbaijan, more than 6.000 from Greece, and another 6.000 from the Russian Federation. In 2005, there were around 132.000 foreign nationals with residence permit in the country, nearly 50.000 from Bulgaria, around 8.000 from Azerbaijan, 7.000 from Germany, almost 5.000 from Iraq, more then 4.000 from Iran, and another 4.000 from the Russian Federation.

When in 2005 a total of 131.594 permits were issued for non-nationals, of which 22.130 were those with work permits and 25.440 were those with studying permits, and the remaining parts were the dependants of those who are working or studying. A vast majority of the remaining residence permits (nearly three-fourths) were issued to ethnic-Turk foreign nationals most of whom came to Turkey to join relatives or friends living in the country, or to study and work for a limited period. Other foreign citizens arriving in Turkey are mostly highly-skilled workers taking up employment with Turkish companies or foreign investment projects located in Turkey.

\section{Concluding Remarks}

In the last two decades Turkey has experienced a fundamental change from being an emigration country to a country attracting migrants of different kinds. While this happens, however, the country has failed in producing adequate statistics to reflect a comprehensive and detailed picture of the migration flows into the country. It appears that the lack of a reliable set of information on immigration in Turkey is partly because of the absence of a fairly established system of the collection and dissemination of data, and partly because of the irregular nature of immigratory flows to the country. It also appears that now while Turkey is in the accession negotiations with the European Union, it does not only try to harmonize its migratory regime with the one in the $\mathrm{EU}$, but it also attempts to establish a statistical system compatible with the one in the EU countries.

In the past, Turkey was considered and indeed felt itself to be a country of emigration. However, since the 1980's it is the immigration flows that have gained growing importance: the country had also increasingly become a transit country of immigrants and asylum seekers. In short, the extend and character of population movements into, through, and out of Turkey has changed. number of political, social, and economic implementations, not only for Turkey, but 
also in the wider context of East-West and South-North migration, particularly for the Turkey's EU affairs. What becomes quite clear over the picture reflected in this essay is the fact that Turkey's international migratory regimes seems to be following the similar patterns of the some migratory regimes in other southern European EU countries such as Portugal, Spain and Greece who were previously only migrantsending states, but later were transformed in to the countries of immigration and transit.

\section{BIBLIOGRAPHY}

BFBA (Bureau for Foreigners, Borders, and Asylum) at the Directorate of General Security of the Turkish Ministry of Interior (2001), Illegal Migration around the World and in Turkey, Ankara, Directorate of General Security of the Ministry of Interior (in Turkish).

İçDUYGU Ahmet (2006a) Turkey andInternational Migration 2005, Istanbul, SOPEMI Report for Turkey.

içDUYGU Ahmet (2006b) Turkey: The Demographic and Economic Dimension of Migration, in Philippe Fargues, ed., Mediterranean Migration 2005 Report, Via delle Fontanelle, European University Institute, RSCAS.

İ̧̧DYGGU Ahmet and ÜNALAN Turgay (2002) Tides between Mediterranean Shores:

Undocumented Migration in the South of Europe, Papers in Demography, no. 7, Hacettepe University Institute of Population Studies.

KíRIş̧̧i Kemal (2006) Turkey: The Political Dimension of Migration, in Philippe Fargues, ed., Mediterranean Migration 2005 Report, Via delle Fontanelle, European University Institute, RSCAS.

FUTO Peter and JANDL Michael eds. (2006) 2005 Year Book on Illegal Migration, Human Smuggling and Trafficking in Central and Eastern Europe, Vienna, ICMPD.

FARGUES Philippe ed. (2006) Mediterranean Migration 2005 Report, Via delle Fontanelle, European University Institute, RSCAS.

TOKUZLU Lami Bertan (2006) Turkey: The Legal Dimension of Migration, in Philippe Fargues ed., Mediterranean Migration 2005 Report, Via delle Fontanelle, European University Institute, RSCAS.

UNHCR United Nations High Commissioner for Refugees (2001), available on-line at http:// www.unhcr.ch

\section{NOTES}

1. For a detailed elaboration of these debates see, for instance, İçduygu, A. (2006a), (2006b); Tokuzlu, L. B. (2006); Kirşçi, K. (2006) and also see the special issue of Turkish Studies, edited by Erzan, R., Kiriş̧̧i, K. 7 (1), 2006.

2. See Commission of the European Communities, Communication from the Commission to the Council and the European Parliament, COM (2004) 656 final, Brussels, 6.10.2004. 
3. See European Commission "Attitudes towards European Union Enlargement" Special Eurobarameter 255/Wave 65.2- TNS opinion \& social fieldwork,March-May 2006, Publication: July 2006.

4. See various issues of SOPEMI Reports for Turkey-2003' prepared by Ahmet İçduygu since 2000.

5. Data used here both for emigration estimates are derived from a variety of sources, such as the Turkish Labour Ministry, the Ministry of the Interior, OECD SOPEMI, Eurostat, UNHCR, UNFPA, and country-specific reports and documents.

6. UNHCR United Nations High Commissioner for Refugees (2001), available on-line at http:// www.unhcr.ch

7. The figures are from BFBA (Bureau for Foreigners, Borders, and Asylum) at the Directorate of General Security of the Turkish Ministry of Interior 2001.

8. For instance, Yaşar Okuyan, the Minister of Labour in the 1999-2002 government often cited the figure of " 1 million illegal migrants" living in Turkey. Later same figure have been mentioned by so many officials in the country.

\section{ABSTRACTS}

Turkey is one of the main actors in the Eurasian migration scene, first as a country of origin and then as a country of destination and transit. Therefore it attaches great importance to the newly diversifying migration questions and their management. This focus has been precipitated by Turkey's desire to enter into the European Union and by recent transformation it has faced that have fueled the need for the creation and implementation of a variety of migration-related policies.

Having put this background aside, the past few years have seen profound transformation in the case of Turkey to address various international and asylum challenges. This essay reviews the panorama of the international migration and asylum issues in Turkey in recent years. Providing some basic statistical data on flows and stocks of migrants, asylum seekers and refugees in the country and interpreting them briefly, it intends to provide us with the main problematic areas of international migration into and out of the country.

Panorama du régime des migrations internationales en Turquie. La Turquie est l'un des principaux acteurs sur la scène des migrations Eurasiennes, d'abord en tant que pays d'origine, ensuite en tant que pays de destination et de transit. Elle attache donc beaucoup d'importance à des questions migratoires qui se sont diversifiées depuis peu, ainsi qu'à leur mode de traitement. L'intérêt pour ces questions s'est rapidement accru grâce u désir de la Turquie de rejoindre l'Union Européenne, ainsi que par les transformations récentes des migrations auxquelles elle a dû faire face, et qui ont alimenté la création et la mise en œuvre d'une série de politiques liées aux migrations. Après avoir assimilé cet arrière-plan, les quelques dernières années ont vu, en Turquie, de profondes transformations dans les façons d'affronter les défis posés par le droit d'asile. Le présent papier passe en revue le panorama des problèmes liés aux migrations internationales et au droit d'asile en Turquie dans la période la plus récente. Il présente quelques données statistiques de base concernant le flux et le stock des migrants, des demandeurs d'asile et des réfugiés dans le pays. Il en donne une rapide interprétation, afin de nous offrir les principaux thèmes des problématiques concernant les migrations internationales vers le pays et vers l'extérieur. 
Panorama del régimen de migraciones internacionales en Turquía. Turquía es uno de los principales actores de la escena de las migraciones euroasiáticas, como país de origen primero y en calidad de país de destilación y de tránsito a continuación. Así, Turquía concede gran importancia a las cuestiones migratorias que, desde hace poco, se han diversificado y también al modo en el que dichas cuestiones son tratadas. El interés por estas cuestiones se ha acrecentado rápidamente gracias al deseo de Turquía de entrar en la Unión Europea y a las transformaciones recientes de las migraciones ante las cuales se encuentra el país y que han alimentado la creación y el desarrollo de una serie de políticas ligadas a las migraciones.

Tras haber asimilado este trasfondo, durante estos últimos años, la manera de afrontar los desafíos del derecho de asilo en Turquía ha sufrido profundas transformaciones. Este artículo analiza el panorama reciente de los problemas ligados a las migraciones internacionales y al derecho de asilo en Turquía. Son presentados datos estadísticos básicos referentes a los flujos y los stock de inmigrantes, de demandantes de asilo y de refugiados del país. El artículo propone una interpretación rápida con el fin de ofrecer los principales temas de las problemáticas relativas a las migraciones internacionales hacia el país y hacia el exterior.

\section{INDEX}

Geographical index: Turquie

\section{AUTHOR}

\section{AHMET IÇDUYGU}

Professor, Dept. of International Relations, Koç University Istanbul, Turkey, aicduygu@ku.ed.tr 